\section{Dollarization as a Monetary Arrangement for Emerging Market Economies}

\author{
Gaetano Antinolfi and Todd Keister
}

E cuador and El Salvador have recently adopted - the U.S. dollar as legal tender, replacing their own national currencies. ${ }^{1}$ This same move has received serious attention in policy debates in both Argentina and Mexico. Abandoning the national currency is a decision with far-reaching economic and political implications that are not well understood. In response to this phenomenon, a growing literature has aimed at evaluating the economic costs and benefits of "dollarizing." In this article, we provide an overview of the emerging literature and point out some issues that we feel warrant further research. ${ }^{2}$

Throughout, we focus on official dollarization, where the U.S. dollar (or some other currency) replaces the national currency as legal tender. Unofficial dollarization, where private agents use a foreign currency as a substitute for the domestic currency, is already widespread in Latin America and elsewhere. We focus on Latin America and the U.S. dollar because of the recent events and policy debates mentioned above. Most of the issues we discuss, however, would apply to any country considering the official adoption of a foreign currency.

Discussions of the optimal monetary and exchange rate arrangements for an emerging market economy have traditionally centered on fixed or flexible exchange rates or (most often) some hybrid of the two, perhaps combined with capital controls or other regulatory measures. We begin our discussion by examining the causes of the current surge of interest in official dollarization. We then turn to

Gaetano Antinolfi is an assistant professor of economics in the Department of Economics, Washington University, and a visiting scholar at the Federal Reserve Bank of St. Louis. Todd Keister is an assistant professor of economics in the Departamento de Economia and Centro de Investigación Económica, Instituto Technológico Autónomo de México (ITAM) and a visiting assistant professor in the Department of Economics, University of Texas at Austin. The authors would like to thank James Morley, Patricia Pollard, Bob Rasche, Mika Saito, and Frank Schmid for helpful comments. William Bock provided research assistance. the details of the issues that we feel are most important in analyzing the potential costs and benefits of dollarizing.

\section{WHY CONSIDER DOLLARIZATION?}

\section{Financial Crises}

The current interest in official dollarization is largely a reaction to the recent string of currency crises. In the past decade, these crises have affected numerous countries, both industrialized (Italy and the United Kingdom in 1992) and emerging markets (Mexico in 1994, and East Asia and Brazil in 1997). Comparing the crises in industrialized countries with those in emerging markets reveals an important difference: although these crises are not costly in terms of lost output for industrialized economies, they are extremely costly for emerging market economies. ${ }^{3}$ For example, in 1995 Mexican gross domestic product (GDP) declined by 7 percent in real per capita terms. (In the years before the crisis, for comparison, real per capita growth ranged between 3 percent and 10 percent.) Moreover, when one emerging economy suffers a crisis, others are often hit by interest rate increases and a recession, as happened in Argentina following the Mexican crisis. This phenomenon is known as contagion.

The events in emerging market economies share certain characteristics that allow us to identify a typical "anatomy" of a crisis. ${ }^{4}$ Beforehand, there is an incipient capital inflow and a corresponding current account deficit. The onset of the crisis is marked by a sudden capital outflow and a large devaluation of the exchange rate. There is often a crisis in the banking system at about the same time. ${ }^{5}$ The result is a sharp and painful fall in output. Much of the current interest in dollarization stems from a strong desire to avoid such crises in the future. Before discussing the potential costs and benefits of

1 Guatemala has also recently adopted the U.S. dollar as legal tender, but it has decided to maintain its own currency in circulation, without fixing a parity with the dollar.

2 The interested reader can find a good, basic introduction to the topic of dollarization in Chang (2000).

3 This reflects the general finding that an exchange rate devaluation is usually contractionary for emerging markets, whereas it is typically expansionary for industrialized countries. See, for example, Edwards (1989).

4 For a detailed discussion, see Calvo (2000).

5 Kaminsky and Reinhart (1999) empirically show that banking crises tend to precede exchange rate crises. 
dollarizing, we look at some of the more traditional approaches to these problems and why they seem to be falling out of favor.

\section{The Fear of Floating}

One approach that naturally comes to mind (to an economist, at least) is to allow prices and quantities to be determined by supply and demand in markets. The definition of a flexible exchange rate system is exactly this: the price of one currency relative to another is determined by the market without any intervention by central banks. That is to say, any current account deficit has to be financed entirely by capital inflows (a financial account surplus) and vice versa, without any change in official reserves.

In reality, however, we do not observe many countries with truly flexible exchange rate systems. Rapid growth in world capital markets has led to a substantial increase in the size of international capital flows. At times, these flows become very volatile; indeed, as we mentioned above, a sudden reversal in capital flows is the typical "spark" of a crisis. Under a pure flexible exchange rate system, such volatility in capital flows causes corresponding volatility in the exchange rate. A volatile exchange rate, in turn, means that relative prices in the economy are volatile, which can be very disruptive to real economic activity.

Calvo and Reinhart (2000) have termed the unwillingness to let exchange rates be completely determined in markets "the fear of floating." They also point out several additional reasons why emerging market economies seem to be averse to floating exchange rates. These include high levels of dollardenominated debt, high-exchange-rate pass through (reflected in domestic inflation), and in general an adverse effect of currency instability on credit market access. In support of their argument, they conduct an empirical analysis comparing the announced exchange rate regime of countries to the actual exchange rate behavior. Their findings indicate that countries classified as letting their exchange rate float, in general, do not. Hence it seems that very few, if any, countries are willing to take this approach.

\section{The Costs of Capital Controls}

Sudden reversals in the flow of capital have been an important and particularly damaging aspect of currency crises. If capital market volatility is the problem, one way of avoiding it is to introduce capital controls. Clearly the aim of such a policy would not be to stop capital inflows, because emerging market economies rely on them for investment, but to diminish their volatility. There is evidence indicating that capital controls involving taxes and reserve requirements can change the composition of capital inflows in favor of long-term investment, and thereby decrease the likelihood of large, sudden outflows. Calvo and Reinhart (1999), however, caution that these results may depend on the accounting classifications of capital flows. In addition, Edwards (1999) argues that, when analyzing the maturity of a country's foreign debt, the relevant concept is residual maturity ${ }^{6}$ rather than contractual maturity. Using data from Chile, Edwards shows that short-term capital controls had a limited effect on Chile's residual maturity of foreign debt and that Chile had higher residual maturity than Mexico (a country without capital controls) at the end of 1996.

More generally, capital controls are typically not considered sound economic policy because they limit the ability of a country to borrow and invest, they hinder international risk sharing and technology transfer, and they prolong the survival of unsustainable domestic policies. The main practical objection to capital controls, however, is that they create a strong incentive for tax evasion and require a costly enforcement apparatus. These problems make them poor candidates for permanent solutions. ${ }^{7}$

\section{The Vanishing Intermediate Regime}

The unwillingness to let exchange rates float and to use direct capital controls has pushed countries toward "intermediate" exchange rate regimes in which official intervention is used to keep the exchange rate within predetermined bounds. This move, however, has been accompanied by the recent crises mentioned previously. This association has led many observers to claim that intermediate exchange rate regimes are no longer viable for emerging market economies. These observers claim that only extreme (totally fixed or totally flexible) exchange rate regimes are viable for emerging market economies. Eichengreen (forthcoming) colorfully likens

\footnotetext{
6 Residual maturity is measured by the value of a country's liabilities that are held by foreigners and mature within a year.

7 See De Grauwe (1996, Chapter 11) and Neely (1999) for an extensive assessment of capital controls. Calvo and Reinhart (1999) provide a discussion related to the context of dollarization.
} 
adopting an intermediate regime to "painting a bull's eye on the forehead of the central bank governor and telling speculators to "shoot here.". 8 There are, of course, situations for which some authors are willing to defend intermediate regimes as appropriate, but they are generally viewed as temporary remedies. ${ }^{9}$ Fischer (2001) presents empirical evidence that the proportion of emerging market economies using intermediate regimes has indeed declined over the past decade.

An important question is how extreme a policy must be in order to avoid the problems associated with the middle ground. Even a currency board has proven not to be extreme enough in some ways. Under this arrangement, the central bank commits to back its monetary base entirely with foreign reserves at all times; thus, a unit of domestic currency can be introduced into the economy only if an equivalent amount of foreign reserves is obtained. In principle, this system is equivalent to dollarization. However, even though Argentina has been operating under a currency board since 1991, the interest rate differentials between peso-denominated and dollar-denominated debt remain and have widened during periods of financial turmoil, as with the Brazilian and Mexican crises (see Figure 1). This indicates that financial markets believe there to be a significant probability that the currency board will be abandoned under such circumstances, and the Argentine economy has suffered as a result.

\section{THE KEY ISSUES}

We now turn to what we see as the key issues in evaluating the costs and benefits of dollarization. Two of the primary benefits of dollarization are straightforward: exchange rate volatility (against the dollar) and exchange rate crises would be eliminated, and in most cases the inflation rate would be lowered substantially. One of the costs is also fairly straightforward, although occasionally misunderstood: the loss of seignorage revenue. We begin our discussion with this issue.

There are other costs and benefits that are more subtle and difficult to measure. Dollarization implies the loss of monetary policy, but, if it enhances the credibility of economic policy, dollarization could lower interest rates and substantially decrease the likelihood of future financial crises. If it increases economic integration with the United States, dollarization could yield substantial benefits in both product and financial markets. An important con- cern, however, is that dollarization would limit the ability of the central bank to act as a lender of last resort. We discuss these issues in turn below. Finally, a discussion of dollarization would not be complete without looking at the "initial conditions" in which many emerging market economies currently find themselves and approaching the issue from the perspective of the United States.

\section{Seignorage Revenue}

An obvious cost of dollarization is the loss of the seignorage revenue that comes with the power to print fiat currency. The size of the flow of seignorage revenue depends on both the rate of growth of output and the rate of inflation. For some emerging market economies, it constitutes a substantial fraction of government revenues. With any other fixedexchange-rate arrangement, seignorage revenues are present in some form. In particular, under a currency board, newly printed domestic money is used to buy interest-bearing foreign reserves. Dollarization entails losing this interest. It also entails buying back the domestic monetary base using foreign reserves and, therefore, losing the interest on this stock of reserves as well. Velde and Veracierto (1999) calculate this latter number for Argentina to be $\$ 658$ million, or 0.2 percent of GDP, per year.

Note that computing the present level of seignorage revenue and calling that a "cost" of dollarization is clearly a mistake in most cases. Chang and Velasco (2000b) make this point: If a country dollarizes in order to lower its inflation rate, this reflects a decision that the benefits of lower inflation outweigh the value of the revenue that higher inflation brings. Instead, one should focus on the seignorage revenue that would have been earned at the new, lower inflation rate. This is the "loss" in seignorage revenue relative to the (ideal) case where the inflation rate is (somehow) lowered without dollarizing.

There are two reasons to believe that this amount may still overestimate the true revenue loss from dollarizing. First, a dollarizing country may be able to negotiate a deal with the United States under which it receives some of the increased U.S. seignorage revenue (which could equal the "loss" calcu-

8 See also Obstfeld and Rogoff (1995) and Summers (1999; 2000, p.8). For a classification of different exchange rate regimes, see Frankel (1999).

9 See Mussa et al. (2000), who argue that an unsustainable policy need not be undesirable in the short run, and Frankel (1999), from whom we borrowed the title of this section. 


\section{Figure 1}

\section{Interest Rates on Loans Given to Prime Companies}

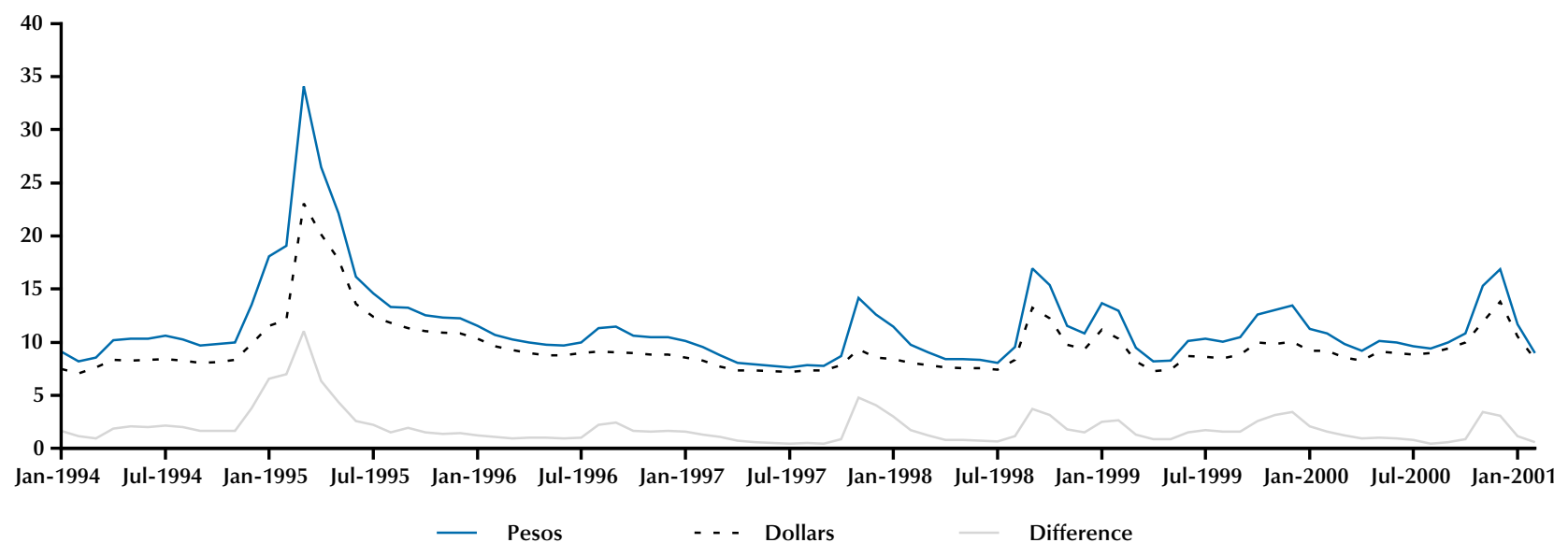

SOURCE: Central Bank of Argentina.

\section{Interest Rates on Deposits (30- to 59-Day Term)}

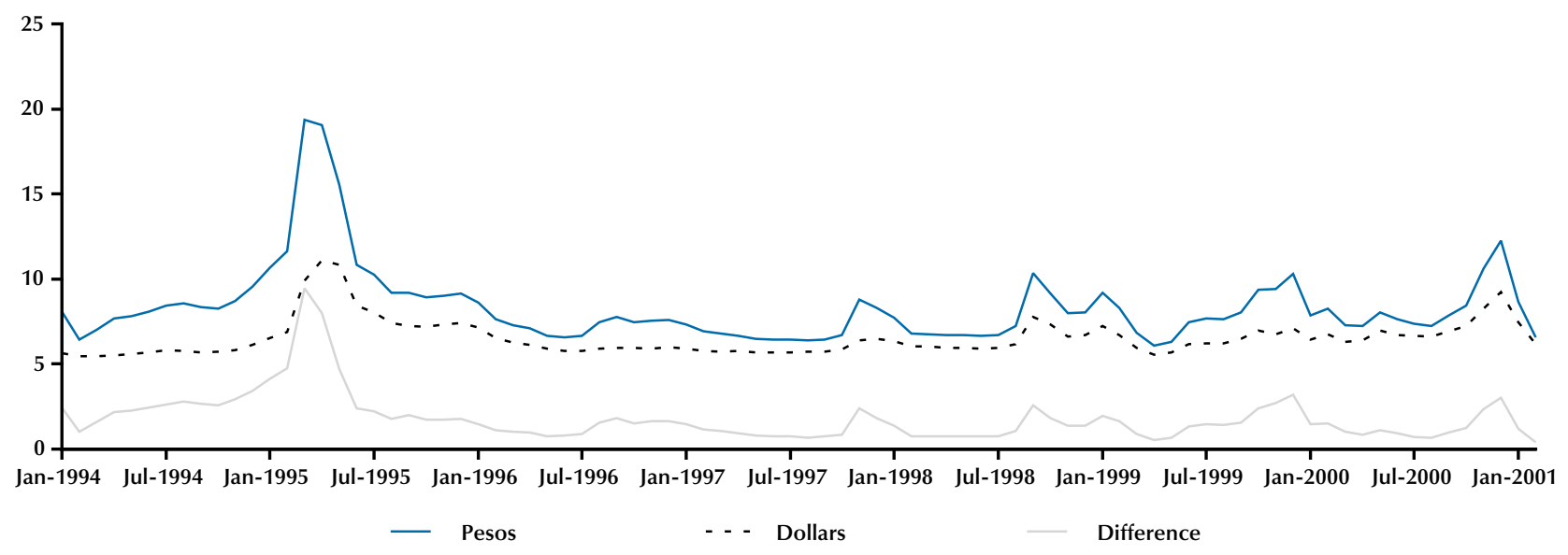

SOURCE: Central Bank of Argentina.

lated above). ${ }^{10}$ Second, a large part of the reason for dollarizing is to create a more stable economic environment that will encourage investment and growth. While it is extremely difficult to make quantitative predictions about the size of this effect, it is clear that the increase in tax revenue from increased economic activity should at least partially offset the loss of seignorage revenue.

Regarding this last point, however, it is important to note that the increase in tax revenue would take time to develop. In the meantime, a government with lower revenues would have to decrease expenditures, increase taxes, or increase the public debt. To the extent that the loss of seignorage revenue is compensated by an increase in government borrowing, it may not be the case that a stable currency necessarily provides more macroeconomic stability. This is an indication that the fiscal plan accompanying a dollarization would be critical to its success.

\footnotetext{
${ }^{10}$ Such a plan was actually proposed as part of the International Monetary Stability Act, introduced by then Senator Connie Mack of Florida. Details can be found in Mack (2000).
} 


\section{Fiscal Consequences}

Because dollarization entails a loss of both seignorage revenue and independent monetary policy, it is likely to have important consequences for the conduct of fiscal policy. Sims (2001) argues against dollarization for precisely this reason. $\mathrm{He}$ argues that the option value of issuing fiat debt (which can be defaulted on through inflation) is too high to surrender because inflation is part of an optimal taxation scheme. In support of his argument, Sims computes the unexpected component of U.S. government debt yields and shows that it is substantial. His calculations show that fiat debt worked to relax the government budget constraint in times of high economic turmoil (such as the oil crisis of 1973). One possible interpretation of this fact is that, without fluctuations in the unexpected component of government bond yields, more variability would have been observed in taxation and government expenditure, which may have been very costly. More research (as Sims acknowledges) is needed to evaluate (i) how much of the variability in the unexpected component of government bond yields actually reflects inefficient variation in monetary and fiscal policy that is better avoided and (ii) how much of it reflects an "optimal" response to real shocks.

Similarly, Chang and Velasco (2000b) argue that an optimal taxation plan would always entail surprise inflation (or devaluation) because this acts as a lump-sum tax and therefore is non-distortionary. Dollarization removes the ability of the government to use this tax. The contributions of Sims (2000) and Chang and Velasco (2000b) in this way stress the potentially high costs of losing flexibility in economic policy. Surprise inflations, however, cannot be repeatedly engineered, and anticipated inflation is typically not part of an optimal taxation plan. Hence the government has a time-consistency problem; it wants to convince people that it will not engineer an inflation increase, but once people are convinced, it wants to surprise them. Because people know this, the economy can end up in a situation of anticipated inflation. If this problem is very costly to the economy, then the benefit of using dollarization to solve it may easily outweigh the cost of the lost flexibility. ${ }^{11}$

Chang and Velasco (2000b) go on to point out that dollarization might decrease the incentives for fiscal discipline. Lack of fiscal discipline, in turn, may mean that crises due to high sovereign default risk would persist and the economy would not benefit from lower interest rates. Would the adoption of the dollar imply more or less fiscal discipline? Chang (2000) argues that, under alternative arrangements, changes in exchange rates or interest rates make the costs of a lack of fiscal discipline immediate. Dollarization would take those incentives away by allowing the costs of present fiscal looseness to be shifted to the future (in terms of higher future taxes, for example). Hence the incentives for fiscal discipline would decrease.

Although these incentive problems are real, it is important to recognize that there are other factors working in the opposite direction. First, as noted above, emerging markets depend heavily on foreign capital, and capital outflows could serve to make the cost of a lack of fiscal discipline immediate. Second, the incentive for domestic investors to monitor and put political pressure on the government for fiscal discipline would be higher. Heavy government borrowing would be perceived to induce macroeconomic instability and would cause interest rates for all domestic borrowers to increase. Through these channels, market discipline would be present for a dollarized government.

If dollarization does undermine the incentives for fiscal responsibility, does that mean it should be accompanied by legal restrictions on the government budget deficit? In part, this was the route taken by the European Monetary Union (EMU) in tying the Stability Pact to the launch of the euro. It is important to notice, however, that a unilateral dollarization is very different from the EMU's in this regard. In the latter case, members relinquished control to a common central bank for the conduct of monetary policy. The decision to dollarize, in contrast, entails total loss of monetary authority. As such, legal restrictions on the government budget would constrain an already shrunken set of policy alternatives, which could prove very costly in an economic downturn. ${ }^{12}$

\section{Economic Integration}

A potential benefit of dollarization is that it could increase the level of integration of the dollarizing economy with the U.S. economy. This may come about for several reasons, including reduced transactions costs and the elimination of uncertainty

\footnotetext{
11 On the optimal-tax property of inflation, see Calvo and Guidotti (1993). For the analysis of time-consistency problems, see Kidland and Precott (1977) and Calvo (1978).

${ }^{12}$ Also, see Ghiglino and Shell (2000) for a discussion of when deficit restrictions do not really constrain the government and hence have no real effects.
} 
about exchange rates. Frankel and Rose (2000) present evidence that currency unions lead to large increases in trade flows between member countries. ${ }^{13}$ Furthermore, Frankel and Rose argue that these increases do not come from the diversion of trade away from non-member countries; rather, currency union membership leads to a higher ratio of total foreign trade to GDP. In fact, they interpret their results as indicating that increased trade is the primary benefit of joining a currency union (or dollarizing).

In addition to increased trade, dollarization could increase the level of financial integration between the dollarizing country and the United States. Stockman (2001) focuses on the "central bank area" that would result from dollarization. He argues that this would be the most important effect of dollarization in Mexico - the Federal Reserve System would become Mexico's central bank.

This scenario would lead to changes in monetary policy (which Stockman defines broadly to include supervisory and regulatory policies) that would affect the incentives of financial intermediaries and thereby affect the levels of investment and financial integration. This change is important because the level of financial development is strongly related to economic growth and is shown in some studies to cause growth ${ }^{14}$; thus, the potential benefits are indeed large.

Other studies, however, indicate that integration should come before dollarization. For example, Bencivenga, Huybens, and Smith (2001) show that dollarization has a different impact depending on the extent of the integration between the two economies' financial markets. They show that dollarization is beneficial when capital markets are well integrated; otherwise, dollarization may be a source of volatility and indeterminacy in the economy. Hence in their model, it is the ex ante level of integration of capital markets that determines the benefits of dollarization.

Bencivenga, Huybens, and Smith (2001) complement and extend the traditional optimal currency literature, where it is the integration of real markets that determines the boundaries of the optimal currency area. This theory is based on the work of Mundell (1961) and specifically addresses the issue of when two economies should use the same cur rency. According to the theory, the key issue in determining whether two economies fall in the same optimal currency area is whether or not there is a substantial benefit of having independent monetary policy to accommodate asymmetric shocks to the economies. An optimal currency area in general is one where: (i) asymmetric shocks are not substantial, (ii) there is high mobility of factors of production, and (iii) prices are flexible. It is important to keep in mind, however, that these considerations have not been the motivation behind the current interest in dollarization.

Using the criteria of the literature on the traditional optimal currency area, it is hard to imagine Argentina being in the same optimal currency area as the United States. Even neighboring Mexico is far from perfectly integrated with the U.S. economy. The interest on dollarization fundamentally stems from the desire to bring about financial stability. The involvement of the banking sector in the recent crises underlined the importance of this issue, which is beyond the scope of the traditional optimalcurrency-area model.

\section{The Lender of Last Resort Function}

A common argument against dollarization is that it would severely limit the ability of the central bank to act as a lender of last resort when the banking sector is in distress. One of the crucial roles that banks perform is maturity transformation: taking in short-term deposits and making long-term loans. This naturally puts a bank at risk if, for whatever reason, depositors have a sudden increase in their demand for liquidity and want to withdraw their money. When there is a domestic currency that can be printed freely, the central bank always has the ability to meet this liquidity demand by lending cash to the banking sector. Banks can then repay the loans when the crisis passes. In a dollarized economy, the central bank would not have unlimited resources to lend. The fear, therefore, is that giving up the ability to print currency will make these types of crises more frequent and/or more severe.

The emerging literature has shown that this concern is likely overstated for several reasons. First, the ability of the central bank to act as a lender of last resort is equally limited under fixed exchange rates and currency boards. Nevertheless, Argentina has developed several other mechanisms to deal

\footnotetext{
${ }^{13}$ For a critique of their result and a review of the literature in contrast with it, see Pakko and Wall (2001).

${ }^{14}$ King and Levine (1993) show that financial development predicts subsequent growth, and Rajan and Zingales (1998) provide evidence of causation. See also Levine (1997). Levine and Carkovic (2001) argue that the positive effects of dollarization would be indirect, working through financial development.
} 
with liquidity crises. These include holding excess foreign reserves (above those required to back the currency in circulation), having banks contribute to a deposit insurance fund, and contracting a type of contingent credit line with foreign banks. Velde and Veracierto (1999) calculate that, together, these mechanisms cover 40 percent of total deposits. Second, as Calvo (2001) points out, central banks in industrialized countries do not generally perform their lender-of-last-resort function by printing currency; they borrow instead. This was the case, for example, in the banking crises in Sweden and Finland in 1992. Third, as proposed by Calvo (2001) and others, a "special fund" or a credit line guarantee from an international lender of last resort could be set up to guard against a large crisis that would overwhelm domestic resources. One potential source of revenue for the fund is the increase in seignorage revenue that the United States would receive when a country dollarizes. Since the fund would likely increase the stability of dollarizedcountry financial markets, this could be a productive (and politically acceptable) use of the funds from the U.S. point of view. ${ }^{15}$

Finally, several studies have identified the domestic lender of last resort as a cause of both excess volatility in emerging economies' financial markets and currency crises. ${ }^{16}$ This is largely related to the moral hazard problem that such a lender can create when the supervisory and regulatory aspects of the banking system are underdeveloped. This problem was particularly severe in East Asia and is now thought to be one of the primary causes of that crisis. ${ }^{17} \mathrm{~A}$ related problem is that the lender of last resort might not be able to take the "right" action in times of crisis because of heavy political pressure. Ennis (2000), for example, shows how such pressure may prevent the lender of last resort from implementing the optimal policy and, instead, force the use of a suboptimal inflation tax to bail out a banking sector in distress. In this context, dollarization works as an ex ante commitment not to surrender to political pressure in the event of a liquidity crisis. Antinolfi and Keister (2000) show how dollarization can be seen as a way of committing to charge a (perhaps unpopular) "penalty rate" on discount window loans during a crisis-exactly the policy advocated by Bagehot (1873). These studies indicate that dollarization can actually be seen as fixing some of the problems created by a lender of last resort. ${ }^{18}$ Such political-economy issues have received relatively little emphasis in the litera- ture on dollarization, and in our opinion they deserve further research.

\section{Existing Liability Dollarization}

The set of initial conditions on which dollarization would be implemented is also crucial for understanding dollarization proposals. Our analysis would be incomplete without a discussion of the current state of an economy considering dollarizing, particularly with respect to existing liability dollarization. Liability dollarization refers to domestic borrowing denominated in or indexed to a foreign currency. Both sovereign debt and private debt in emergingmarket economies are often dollarized.

Our main concern in this section is private sector dollar-denominated debt, which has been growing rapidly in emerging-market economies. This includes both direct borrowing by individual firms and borrowing by the domestic banking sector. Is widespread liability dollarization an indication that an economy should officially dollarize? The answer to this question must depend on what is causing the liability dollarization to occur. Why are firms willing to borrow in a foreign currency when this creates a balance-sheet mismatch that greatly increases their vulnerability to unexpected devaluations?

Two types of explanations have been offered in the literature. The first (see, for example, Burnside, Eichenbaum, and Rebelo, 2001) is based on (implicit or explicit) government guarantees of the liabilities, especially those of the banking system. Under a fixed exchange rate regime, the interest rate on dollar loans will be lower than the domestic interest rate, the difference reflecting the possibility of devaluation. This condition leads banks to borrow in dollars. In addition, because the government guarantee implies that it will act as a residual claimant on bank

\footnotetext{
${ }^{15}$ Clearly, any such contribution of seignorage would be a matter for the Congress and executive branch to decide.

${ }^{16}$ See, for example, Chang and Velasco (2000a), Mishkin (1999), and Fischer (1999). See also Antinolfi, Huybens, and Keister (2001), which shows how a lender of last resort having the ability to print money can allow inflationary beliefs to become self-fulfilling.

${ }^{17}$ See Corsetti, Pesenti, and Roubini (1999) and Mishkin (1999) on this topic.

${ }^{18}$ But would dollarization itself find the necessary political support to be implemented? Ennis (2000) goes on to show that this is possible if the economy has a large population of international banks (i.e., banks that operate in several countries). It is interesting to note that this is, in essence, a form of financial-market integration, which we saw above (in a different context) to be a factor that is likely to increase the probability of success with dollarization.
} 
assets in bad states of the world (in which banks go bankrupt), banks face no ex ante incentives to purchase insurance against bad states of the world. Hence, they do not hedge (sufficiently) against foreign exchange risk. In other words, the guarantee creates a moral hazard problem that leads to a fragile banking system that is overexposed to currency risk. The reason the government would provide this guarantee is that it reduces the interest rate that domestic firms pay when financing working capital from domestic banks and, therefore, has positive effects on economic growth. This benefit the government obtains is sufficient to overcome the cost of increasing the probability of a banking crisis when the exchange rate is devalued. This is an indication that official dollarization may be warranted, as it would bring this benefit without the cost.

The second type of explanation claims that liability dollarization is a result of underdeveloped domestic financial markets (see Caballero and Krishnamurthy, 2000). The underdevelopment means that firms cannot pledge their entire return to foreign investors. As a result, assets that can be used as international collateral become essential. In such an environment, individual firms choose between borrowing in local currency (which is immune to changes in the exchange rate) and borrowing in dollars (which is cheaper). Caballero and Krishnamurthy (2000) interpret borrowing in domestic currency as purchasing insurance against exchange rate fluctuations. They go on to show how competitive markets mis-price this insurance. This problem happens because, at the firm level, there are two types of collateral-internationally accepted and domestically accepted assets. At the economywide level, however, only internationally accepted assets are net collateral. Because firms "overestimate" the amount of collateral that they have available, they tend to purchase less insurance than would otherwise be optimal. If this is the reason for the observed liability dollarization, it is less clear that officially dollarizing would help matters. The problem of scarce internationally accepted collateral may still arise. In this case, the benefit of official dollarization is likely to be indirect-through the development of domestic financial markets and their integration with international markets.

\section{The Effects from the Perspective of the United States}

Our discussion so far has focused on the potential costs and benefits of dollarization from the viewpoint of the economy considering dollarizing. The view of dollarization from the perspective of the United States is also important. When Ecuador and El Salvador adopted the dollar, the impact on the United States was clearly minimal. It is doubtful that the same could be said about Argentina or, especially, Mexico. Two areas where a large dollarization could have an important impact on the United States are seignorage revenue and the conduct of monetary policy.

We have discussed above how dollarization entails a transfer of seignorage revenue from the dollarizing government to the United States. We have also discussed how the dollarizing country might like to either receive a share of this money or have it set aside in a fund for lender-of-last-resort functions. The second plan might receive more support in the United States, since otherwise the United States would possibly be directly involved in trying to alleviate banking crises. This possibility introduces interesting questions about the relationship between the United States and the dollarized economies that the literature has yet to explore. To the extent that the United States perceives there to be costs to having the dollar used widely, it may be reluctant to give up the benefit of the extra revenue.

The financial integration with the United States that could follow a dollarization is commonly considered to be a major benefit of dollarizing. Arguably, financial integration can prove to be a major benefit also for the U.S. economy. In addition, however, U.S. monetary policy will have stronger effects abroad, and the United States might have to take these effects into account. As an example, suppose there is a recession in a dollarized Mexico that calls for a looser policy while events in the United States call for a tighter policy. Although the United States would have the option of ignoring events in Mexico, doing so would likely cause a significant increase in the flow of illegal immigrants into the United States. Hence the optimal policy (from a selfish point of view) would likely be looser than it would have been had Mexico kept the peso. ${ }^{19}$ In this way, it is not only the dollarizing economy that is losing monetary independence; the United States might lose some as well.

\footnotetext{
${ }^{19}$ For an analysis of the potential relation between dollarization and Mexican migration to the United States see Borjas and O'N. Fisher (2001). Their results indicate that the flow of illegal immigrants is more volatile when Mexican authorities adopt a fixed exchange rate, whereas the flow of legal immigrants remains unaffected.
} 
As a final (and highly speculative) note, we observe that, if the United States benefits from the increase in seignorage revenue, widespread dollarization would give an incentive to generate a higher steady-state level of inflation. Although it seems unlikely that this incentive would influence U.S. policy, it is interesting to report how Fischer (1982) concludes his paper:

Use of a foreign money also implies that the domestic government is relying on the foreign government to maintain better control over the inflation rate than it does itselfan admission that most governments would be reluctant to make. And besides, Who is to guard the guardians?

\section{FURTHER READING}

We have discussed some of the key issues that are important for a country considering official dollarization, including some of the likely costs and benefits. A crucial issue that we have not discussed, however, is how large these costs and benefits would be. There is little historical evidence that can be used as guidance on this question. There are many inherent difficulties in quantifying the effects of dollarization, and these are reflected in a wide range of predictions that are obtained from different models that focus on different aspects of the problem. An example of this disparity can be found in the results of Cooley and Quadrini (2001), Del Negro and Obiols-Homs (2001), Mendoza (2001), and SchmittGrohé and Uribe (2001), all of which are quantitative studies related to dollarization in Mexico. Some of these papers conclude that the overall benefits would be very large, while others conclude they would be small or even negative.

All four of these papers, along with some others we have referenced and some we have not, are gathered together in a special issue of the Journal of Money, Credit, and Banking (May 2001). We encourage the interested reader to consult this source directly for a more extensive discussion of the issues related to dollarization than is possible here. In addition, Spanish-speaking readers are encouraged to consult La Dolarización como Alternativa Monetaria para México (Del Negro et al., forthcoming). This volume consists largely of papers presented at a conference on dollarization sponsored by the Instituto Technológico Autónomo de México (ITAM) in December 2000.

\section{REFERENCES}

Antinolfi, Gaetano; Huybens, Elisabeth and Keister, Todd. "Monetary Stability and Liquidity Crises: The Role of the Lender of Last Resort." Journal of Economic Theory, 2001, 99(1-2), pp. 187-219.

and Keister, Todd. "Liquidity Crises and

Discount Window Lending: Theory and Implications for the Dollarization Debate." Working Paper 00-02, Centro de Investigación Económica, September 2000.

Bagehot, Walter. Lombard Street. London: William Clowes and Sons, 1873.

Bencivenga, Valerie; Huybens, Elisabeth and Smith, Bruce D. "Dollarization and the Integration of International Capital Markets: A Contribution to the Theory of Optimal Currency Areas." Journal of Money, Credit, and Banking, May 2001, 33(2, Part 2), pp. 548-89.

Borjas, George J. and O’N. Fisher, Eric. "Dollarization and the Mexican Labor Market." Journal of Money, Credit, and Banking, May 2001, 33(2, Part 2), pp. 626-47.

Burnside, Craig; Eichenbaum, Martin and Rebelo, Sergio. "Hedging and Financial Fragility in Fixed Exchange Rate Regimes." European Economic Review, 2001, 45(7), pp. 1151-93.

Caballero, Ricardo J. and Krishnamurthy, Arvind. "Dollarization of Liabilities: Underinsurance and Domestic Financial Underdevelopment.” Working Paper No. 7792, National Bureau of Economic Research, July 2000.

Calvo, Guillermo A. "On the Time Consistency of Optimal Policy in a Monetary Economy." Econometrica, 1978, 46(6), pp. 1411-28.

"Balance of Payments Crises in Emerging

Markets: Large Capital Inflows and Sovereign Governments," in Paul Krugman, ed., Currency Crises. Chicago: University of Chicago Press, 2000.

"Capital Markets and the Exchange Rate, with Special Reference to the Dollarization Debate in Latin America." Journal of Money, Credit, and Banking, May 2001, 33(2, Part 2), pp. 312-34.

and Guidotti, Pablo E. "On the Flexibility of Monetary Policy: The Case of the Optimal Inflation Tax." Review of Economic Studies, 1993, 60, pp. 667-87. 
and Reinhart, Carmen M. "When Capital Inflows Come to a Sudden Stop: Consequences and Policy Options." Unpublished manuscript, June 1999. and . "Fear of Floating."

Unpublished manuscript, September 2000.

Chang, Roberto. "Dollarization: A Scorecard." Federal Reserve Bank of Atlanta Economic Review, Third Quarter 2000, 85(3), pp. 1-11.

and Velasco, Andres. "Financial Fragility and

the Exchange Rate Regime." Journal of Economic Theory, 2000a, 92(1), pp. 1-34.

and "Dollarization: Analytical Issues.” Unpublished manuscript, August 2000b.

Cooley, Thomas F. and Quadrini, Vincenzo. "The Costs of Losing Monetary Independence: The Case of Mexico.” Journal of Money, Credit, and Banking, 2001, 33(2, Part 2), pp. 370-97.

Corsetti, Giancarlo; Pesenti, Paolo and Roubini, Nouriel. "What Caused the Asian Currency and Financial Crisis?" Japan and the World Economy, 1999, 11, pp. 305-73.

De Grauwe, Paul. International Money. 2nd Ed. Oxford: Oxford University Press, 1996.

Del Negro, Marco; Huybens, Elisabeth and HernándezDelgado, Alejandro, eds., La Dolarización como Alternativa Monetaria para México. Mexico City: Fondo de Cultura Económica, forthcoming.

and Obiols-Homs, Francesc. "Has Monetary Policy Been So Bad That It Is Better to Get Rid of It?" Journal of Money, Credit, and Banking, May 2001, 33(2, Part 2), pp. 404-33.

Edwards, Sebastian. Real Exchange Rates, Devaluation, and Adjustment. Cambridge, MA: MIT Press, 1989.

"International Capital Flows and the Emerging Markets: Amending the Rules of the Game?" Federal Reserve Bank of Boston Conference Series 43, June 1999, pp. 137-57.

Eichengreen, Barry. "What Problems Can Dollarization Solve?” Journal of Policy Modeling, forthcoming.

Ennis, Huberto M. "Banking and the Political Support for
Dollarization." Working Paper 00-12, Federal Reserve Bank of Richmond, December 2000.

Fischer, Stanley. "Exchange Rate Regimes: Is the Bipolar View Correct?" Distinguished Lecture on Economics in Government, American Economic Association Meetings, January 2001. < http://www.imf.org/external/np/speeches/ 2001/010601a.htm > .

"On the Need for an International Lender of Last Resort." Journal of Economic Perspective, Fall 1999, 13, pp. 85-104.

"Seignorage and the Case for a National Money." Journal of Political Economy, 1982, 90(2), pp. 295-313.

Frankel, Jeffrey A. "No Single Currency Regime Is Right for All Countries at All Times.” Working Paper No. 7338, National Bureau for Economic Research, September 1999. and Rose, Andrew K. "Estimating the Effects of Currency Unions on Trade and Output." Working Paper No. 7857, National Bureau for Economic Research, August 2000

Ghiglino, Christian and Shell, Karl. "The Economic Effects of Restrictions on Government Budget Deficits." Journal of Economic Theory, 2000, 94(1), pp. 106-37.

Kaminsky, Graciela L. and Reinhart, Carmen M. "The Twin Crises: The Causes of Banking and Balance of Payments Problems." American Economic Review, 1999, 89, pp. 473-500.

King, Robert G. and Levine, Ross. "Finance, Entrepreneurship, and Growth." Journal of Monetary Economics, 1993, 33(3), pp. 513-42.

Kydland, Finn E. and Prescott, Edward C. "Rules Rather Than Discretion: The Inconsistency of Optimal Plans." Journal of Political Economy, 1977, 85(3), pp. 473-92.

Levine, Ross. "Financial Development and Economic Growth: Views and Agenda." Journal of Economic Literature, 1997, 35(2), pp. 688-726.

and Carkovic, Maria. "How Much Bang for the Buck? Mexico and Dollarization.” Journal of Money, Credit, and Banking, May 2001, 33(2, Part 2), pp. 339-63.

Mack, Connie. "Dollarization and Cooperation to Achieve 
Sound Money." Speech given at the Federal Reserve Bank of Dallas, 6 March 2000. < http://www.dallasfed.org/ htm/dallas/events/mack.html > .

Mendoza, Enrique G. "The Benefits of Dollarization When Stabilization Policy Lacks Credibility and Financial Markets Are Imperfect." Journal of Money, Credit, and Banking, 2001, 33(2, Part 2), pp. 440-74.

Mishkin, Frederic S. "Lessons from the Asian Crisis." Journal of International Money and Finance, 1999, 18, pp. 709-23.

Mundell, Robert. "A Theory of Optimum Currency Areas." American Economic Review, 1961, 51, pp. 657-65.

Mussa, Michael; Masson, Paul; Swoboda, Alesander; Jadresic, Esteban; Mauro, Paolo; Berg, Paolo and Berg, Andy. "Exchange Rate Regimes in an Increasingly Integrated World Economy.” Occasional Paper No. 193, International Monetary Fund, August 2000.

Neely, Christopher J. "An Introduction to Capital Controls." Federal Reserve Bank of St. Louis Review, Novemberl December 1999, 81(6), pp. 13-30.

Obstfeld, Maurice and Rogoff, Kenneth. "The Mirage of Fixed Exchange Rates.” Journal of Economic Perspectives, Fall 1995, 9(4), pp. 73-96.

Pakko, Michael R. and Wall, Howard J. "Reconsidering the
Trade-Creating Effects of a Currency Union." Federal Reserve Bank of St. Louis Review, September/October 2001, 83(5), pp. 37-46.

Rajan, Raghuram G. and Zingales, Luigi. "Financial Dependence and Growth." American Economic Review, 1998, 88, pp. 559-86

Schmitt-Grohé, Stephanie and Uribe, Martín. "Stabilization Policy and the Cost of Dollarization," Journal of Money, Credit, and Banking, 2001, 33(2, Part 2), pp. 482-509.

Sims, Christopher A. "Fiscal Consequences for Mexico Adopting the Dollar." Journal of Money, Credit, and Banking, 2001, 33(2, Part 2), pp. 597-616.

Stockman, Alan C. "Optimal Central Bank Areas, Financial Intermediation, and Mexican Dollarization." Journal of Money, Credit, and Banking, May 2001, 33(2, Part 2), pp. 648-66.

Summers, Lawrence H. "International Financial Crises: Causes, Prevention, and Cures." American Economic Review, 2000, 90(2), pp. 1-16.

Testimony before the Senate Foreign Relations Subcommittee in International Economic Policy and Export/Trade Promotion, 27 January 1999.

Velde, François R. and Veracierto, Marcelo. "Dollarization in Argentina." Chicago Fed Letter No. 142, June 1999. 
REVIEW 